\title{
A new technique in the evaluation of strangulated and incarcerated hernias: Near-infrared spectroscopy
}

\author{
Murat Ziyan, M.D., ${ }^{1} \odot$ Asım Kalkan, M.D., ${ }^{\circ} \odot$ Özlem Bilir, M.D., ${ }^{1} \odot$ Gökhan Ersunan, M.D., ${ }^{1}$ \\ Deniz Özel, M.D., ${ }^{3}$ ๑ Özlem Uzun, M.D., ${ }^{4}$ ๑ Semih Korkut, M.D. ${ }^{5}$
}

\author{
${ }^{1}$ Department of Emergency Medicine, Recep Tayyip Erdoğan University Faculty of Medicine, Rize-Turkey \\ ${ }^{2}$ Department of Emergency Medicine, Okmeydani Training and Research Hospital, İstanbul-Turkey \\ ${ }^{3}$ Department of Biostatistics, Akdeniz University Faculty of Medicine, Antalya-Turkey \\ ${ }^{4}$ Department of Emergency Medicine, Bağcılar Training and Research Hospital, İstanbul-Turkey \\ ${ }^{5}$ Department of Emergency Medicine, Kartal Dr. Lütfi Kırdar Training and Research Hospital, İstanbul-Turkey
}

\begin{abstract}
BACKGROUND: The present study aims to investigate the usefulness of NIRS in identifying decreased blood flow in intestinal tissue inside the hernial sac in incarcerated hernias.

METHODS: Forty patients with manually irreducible inguinal hernias and with ileus determined by clinical findings and imaging were included in this study. Patients' intestinal oxygenatıons were measured by placing NIRS probes over the areas of inguinal hernia and over non-herniated areas immediately lateral to these. Differences in oxygenation between normal and herniated areas were evaluated.

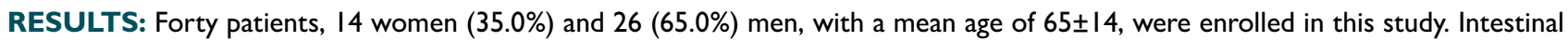
oxygenation was lower in areas of irreducible hernia compared to normal regions $(p<0.001)$. Incarceration and/or strangulation were detected when hernial sacs with low intestinal oxygenation were operated on. Low NIRS measurements were able to identify incarceration and/or strangulation in the intestine but were unable to distinguish between them.
\end{abstract}

CONCLUSION: In conclusion, in the light of the findings of this study, although not capable of differentiating incarceration from strangulation, NIRS appears to be a good method for showing impaired intestinal oxygenation. NIRS can be used to support ultrasonography findings in irreducible hernias. Therefore, this technique could be used in the future to evaluate and monitor intestinal oxygenation in the Emergency Department.

Keywords: Intestinal oxygenation; irreducible inguinal hernia; oximetry.

\section{INTRODUCTION}

Hernia is defined as an internal or other organ extending through the muscle tissue anterior to it and protruding from the abdominal wall. The protrusion of the intestines through the inguinal canal is known as inguinal hernia. Incarceration is defined as the impossibility of returning the intestines protruding through the abdominal wall back inside the abdomen (irreducible hernia). Impaired blood flow in the incarcerated intestine is known as a strangulated hernia (Fig. I). Necrosis may also occur in the intestinal wall in association with impaired blow flow in the event of strangulation. Irreducible hernias of the intestinal wall represent an important proportion of cases presenting at the Emergency Department due to abdominal pain. Emergency surgery due to incarceration and obstruction may be required in 5-13\% of the patients with an abdominal wall hernia. In addition, resection is required due to necrosis in $10-15 \%$ of the cases of the strangulated abdominal wall hernia. The fundamental problem in incarcerated hernias is whether ischemia will develop in the intesti-

Cite this article as: Ziyan M, Kalkan A, Bilir Ö, Ersunan G, Özel D, Uzun Ö, et al. A new technique in the evaluation of strangulated and incarcerated hernias: Near-infrared spectroscopy. Ulus Travma Acil Cerrahi Derg 2020;26:178-185.

Address for correspondence: Asım Kalkan, M.D.

Okmeydanı Egitim ve Araştırma Hastanesi, Acil Tip Kliniği, 34384 Şişli, İstanbul, Turkey

Tel: +90 212 - 3145555 E-mail: drasimkalkan@hotmail.com

Ulus Travma Acil Cerrahi Derg 2020;26(2):178-185 DOI: 10.14744/tjtes.2019.72627 Submitted: I4.II.2018 Accepted: 21.05.2019 Online: 02.03.2020

Copyright 2020 Turkish Association of Trauma and Emergency Surgery 


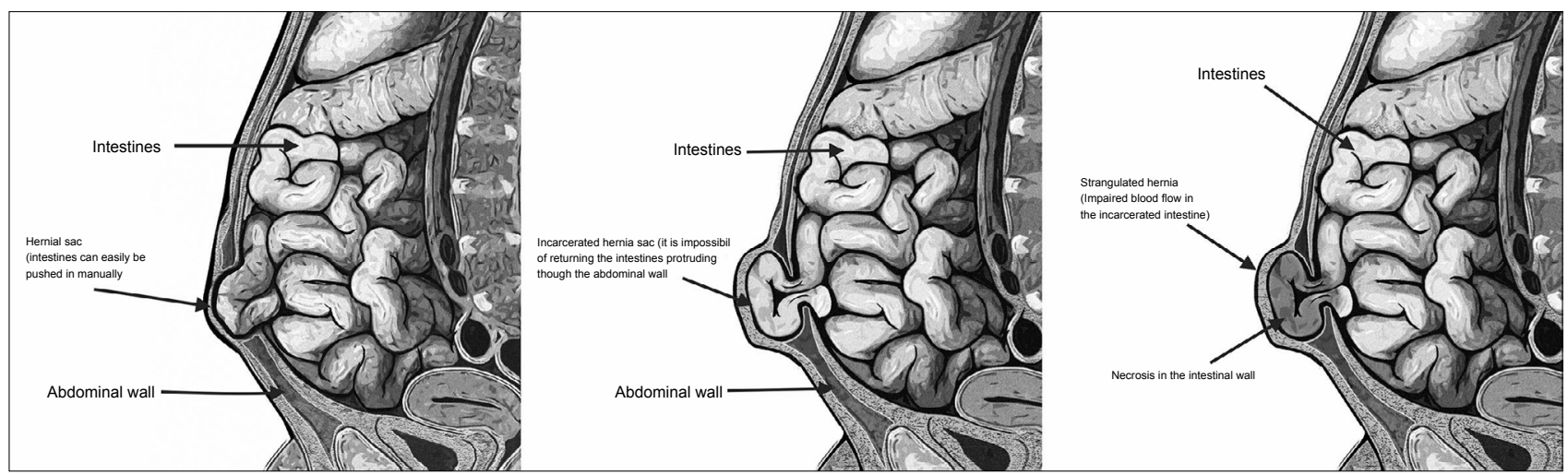

Figure 1. Anatomical descriptions of the normal hernial sac, incarcerated hernia and strangulated hernia.

nal tissue that cannot be returned back inside the abdomen. The basic treatment in both incarceration and strangulation is surgical abdominal wall repair involving returning the intestinal tissue within the hernial sac inside the abdomen. Since necrosis occurs in the intestines in strangulation, this region requires resection, which gives rise to increased morbidity and mortality in strangulated hernias. ${ }^{[1]}$

Near-infrared spectroscopy (NIRS) has a wide range of scientific applications, from agriculture to medicine. While in medical terms, NIRS is more concerned with cerebral oxygenation, in recent years, it has begun to be used to assess oxygenation of all tissues. Although there have been many studies of brain tissue oxygenation, the use of NIRS in assessing oxygenation of the intra-abdominal organs and intestines is particularly noteworthy. ${ }^{[2-6]}$ In an experimental study by Gay et al.," ${ }^{[7]}$ which evaluated oxygenation of the intra-abdominal organs and intestines in piglets using NIRS, reduced blood flow was reported in the intestine and intra-abdominal organs in animals with induced hemorrhagic shock. No significant difference was determined between invasive methods and NIRS measurements. The authors concluded that NIRS probes attached to the anterior abdominal wall of the animals assessed the oxygenation of intra-abdominal organs and intestines as effectively as invasive methods. Various studies of large intestinal wall ischemia, or necrotizing enterocolitis, have reported that NIRS measurements from the anterior abdominal wall are useful in predicting the development of necrotizing enterocolitis. ${ }^{[3,8,9]}$ These studies have essentially been based on determining a decrease in blood flow to the intestines. Bozzetti et al. ${ }^{[10]}$ compared Doppler ultrasound and NIRS measurements concerning blood flow in the mesenteric artery, the artery supplying the intestines. Newborn infants, with immature intestines, are known to be predisposed to necrotizing enterocolitis. Studies emphasizing the importance of monitoring intestinal oxygenation have compared intestinal blood flow before and after oral nutrition using NIRS and have maintained that NIRS is useful for that purpose. In a previous experimental animal study by the current study authors, NIRS was used to evaluate intestinal oxygenation. Measurements of intestinal oxygenation were taken from the abdominal anterior wall at specific intervals in animals following ligation of the mesenteric arteries providing blood supply to the intestines. Lower intestinal oxygenation was determined compared to pre-mesenteric artery ligation values and compared to healthy animals. ${ }^{\left[{ }^{\prime \prime}\right]}$ Although ultrasonography can be used to assess oxygenation in the hernia sac in incarcerated hernias, it has $74.5 \%$ specificity and $92 \%$ sensitivity. In addition, ultrasonographic findings may vary depending on the experience of the operator. ${ }^{[12-14]}$ Therefore, there is a need for additional methods capable of supporting other techniques in the determination of oxygenation of intestinal tissue in incarcerated hernias and of corroborating hypoxia findings.

In the light of the above research, the basic aim of this study was to investigate the usefulness of NIRS in identifying decreased blood flow in intestinal tissue inside the hernial sac in incarcerated hernias.

\section{NIRS}

Recent years have witnessed significant use of photonic technologies to assist the medical and biological investigation of a range of different organisms (including cells, small animals, and humans). Spectroscopy and biological tissue imaging now provide a broad sphere of application for light-based technologies. The concept of light usually refers to the visible (400-700 nm, VIS) and near-infrared (700-2000 nm, NIR) areas of the spectrum. In common with numerous other materials, biological tissues are opaque to VIS and NIR light due to factors, including light absorption and dispersion. These phenomena derive from frequency changes exhibiting dielectric characteristics taking place at the microscopic level. Light absorption is partly caused by the presence of chromophores, including hemoglobin, water, fats, and collagen, in biological tissues. Light dispersion is affected by the shape and size of cells and intracellular structures (including nuclei, and mitochondria). Light dispersion in a specific tissue is thus determined by the effects of absorption and scattering. Light dispersion values range between 5 and $30 \mathrm{~cm}$ in the VIS and NIR spectrum range, but absorption values are very much lower, at $0.02-2 \mathrm{~cm}^{-1}$, meaning that biological tissues are regarded as light-dispersive. Hemoglobin exhibits a high absorption co- 
efficient at short wavelengths $(<600 \mathrm{~nm})$, and water a high coefficient at longer wavelengths (>1100 nm), meaning that light can only penetrate tissue by a few millimeters. Light absorption in therapeutic and diagnostic ranges $(650-850 \mathrm{~nm})$ is usually very low $\left(<0.2 \mathrm{~cm}^{-1}\right)$, limiting the tissue-penetrating capacity of light. Optic mammography and muscle and brain oximetry capable of deep and non-invasive tissue examination are therefore used in medical procedures. ${ }^{[15]}$

The significant attenuation of NIR light occurring in biological tissue results from hemoglobin, a chromophore, in small vessels ( $<1 \mathrm{~mm}$ in diameter) of the microcirculation, such as capillary, arteriolar and venous beds. Since vessels $>1 \mathrm{~mm}$ in diameter absorb light completely, NIRS exhibits low sensitivity to these. The arterial compartments contain $30 \%$ of the blood in the human brain, and NIRS basically measures changes in oxygenation in venous blood. ${ }^{[16]}$

\section{Oximeters INVOS-5100c (INVOS 5100c Covidien, Boulder, CO, USA)}

The terms diffuse optical spectroscopy (DOS) and diffuse optical imaging (DOI) refer to methodologies using VIS and NIR to examine diffusive environments in biological tissues in a non-invasive manner. In DOS measurement, light is typically transmitted to and collected from the sample using optical fibers (optodes), or otherwise, by placing light sources and detectors in direct contact with the tissue under examination.

The simplest DOS measurement configuration is the transmittance state, in which the injection and collection fibers are installed on opposite surfaces. The reflectance-mode exploits that due to scattering, light is highly diffused in the sample volume, and DOS measurements can be made by placing a pair of optic fibers on the same surface of the tissue a few centimeters apart. For DOI, several injection and collection fibers permit topographic or tomographic procedures in a regularly spaced arrangement. ${ }^{[17]}$

Three different DOS/DOI applications can be performed, independently of the measurement geometry:

I) Continuous-wave (CW) DOS/DOI uses a quadrature state light source (such as a light-emitting diode or continuous intensity laser) capable of modulation to a low frequency (several $\mathrm{kHz}$ ) using the attenuator in phase-locked detection techniques and a detection device sensitive to light weakening changes (photodiode),

2) Frequency domain (FD) DOS/DOI is based on amplitudemodulated light sources (at $100 \mathrm{MHz}$ or higher frequencies or up to $\sim \mathrm{GHz}$ ) and detection of light modulation and demodulation phase changes,

3) Time domain (TD) DOS/DOI uses a pulsed light source. It typically uses a laser providing a light pulse lasting a few picoseconds and a sub-nanosystem scale with a temporal resolution detection device. ${ }^{[18]}$

The INVOS-5100c CW procedure used in the current study used a single light source and near-field detectors. Spatiallyresolved NIR evaluated the scattering components of light attenuation and permitted an absolute evaluation of the total hemoglobin ratio expressed as the percentage of $\mathrm{HbO2}$ (oxyhemoglobin) oxygen saturation. ${ }^{[4,19]}$

As a general rule, photons are dispersed by passing through a 'banana-shaped' area, and the depth of their penetration is directly proportional to the distance of the source-detector. The INVOS 5100 device (Somanetics/Covidien, Mansfield, USA) measures the tissue oxygenation percentage known as the total oxygen index (TOl). It also permits the evaluation of fractional tissue oxygen extraction (FTOE), the balance between the oxygen to be used by the tissue and the delivery of that oxygen. ${ }^{[20,21]}$

This value is expressed as a percentage representing saturation.

In the current study, intestinal oxygenation inside the hernial sac was compared with measurements from the normal abdominal region in the same patient. Comparisons were also made of the hernial sac measurements and normal region measurements in all patients.

\section{MATERIALS AND METHODS}

\section{Study Design}

Following approval from the local Ethics Committee, this study was performed in the Emergency Department (ED) of the Recep Tayyip Erdogan University Training and Research Hospital between January 2013 and October 2014. This ED is in a tertiary healthcare institution serving a mean 150,000 patients a year on the basis of existing conditions and criteria in Turkey.

\section{Patients}

Age, gender, additional disease and number of hours of pain in patients presenting at the ED were recorded at the time of presentation. The patient group enrolled in this study consisted of patients with a manually irreducible abdominal wall hernia. Inclusion criteria were age $>18$ years, location of the hernial sac in the abdominal wall, that the hernia was manually irreducible, and findings of ileus, strangulation or incarceration on radiographic imaging (direct abdominal radiography in the standing position or supported by ultrasonography). Patients aged $<18$ years, morbidly obese patients and patients for whom radiological images did not support strangulation or incarceration were excluded from this study. Patients with hyperbilirubinemia were also excluded from this study since 


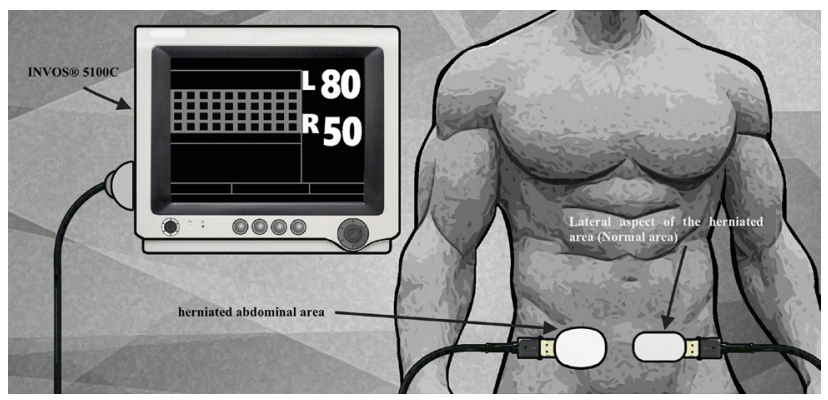

Figure 2. Measurements performed by attaching the NIRS probes above the inguinal hernial sac and to the healthy abdominal region.

this might affect NIRS measurements. A total of 70 patients with abdominal hernia were identified as a result of physical examination and radiological tests. Of these patients, 20 were morbidly obese, two had hyperbilirubinemia and eight had no external abdominal wall hernia, and these were excluded from this study, leaving a total of 40 patients for evaluation.

\section{NIRS Measurements}

NIRS is capable of measuring FTOE. While capable of exhibiting individual differences, some studies have regarded decreases of $25 \%$ from baseline tissue oxygenation as a hypoxia marker. ${ }^{[2]}$ One study of volunteers compared INVOS and EQUANOX oximetry measurements by inducing hypoxia, hyperoxia and reperfusion in the right and left legs and no difference was determined between the two measurements. Baseline INVOS measurements of $81 \% \pm 9 \%$ were determined in the right and left legs, compared to $52 \% \pm 11 \%$ in cases of hypoxia. ${ }^{[23]}$ Thus, we decided to use this value. After the herniated abdominal areas had been cleaned, the NIRS probe was attached. Another probe was attached immediately to the lateral aspect of the herniated area, again including the intestinal segments. Patients were monitored with INVOS $®$ $5100 \mathrm{C}$ device somatic probes (Fig. 2). After measurements had been recorded for approximately $5 \mathrm{~min}$, they were then recorded as the minimum and maximum values. Herniated intestinal segment and non-herniated normal region mea- surements were recorded, and the differences between them were subjected to statistical analysis.

\section{Statistical Analysis}

Descriptive statistics were expressed as frequency, percentage, mean, standard deviation and median, maximum and minimum values. The Mann-Whitney $U$ test and Independent Samples t-test were used for the analysis of differences between measurement values in the comparison of normal NIRS, hernial NIRS and delta values in the strangulated and incarcerated groups. The Paired t-test was used for the analysis of differences between dependent variables in the comparisons of normal and hernial NIRS values. Receiver Operating Characteristics (ROC) analysis was performed for the calculation of sensitivity, specificity and area under the curve (AUC) values of specific variables for the differentiation of patients with incarceration/strangulation. A value of $p<0.5$ was accepted as statistically significant. Analyses were performed on SPSS 18.00 (SPSS, Chicago, IL, USA) software.

\section{RESULTS}

A total of 40 patients were included in this study comprising $26(65.0 \%)$ males and $14(35.0 \%)$ females with a mean age of $65 \pm 14$ years (range, 29-92 years). The decision to operate was made in cases where a hernia was determined, which was not reducible manually. Following surgery, strangulation was detected in 24 (60\%) patients and incarceration in 16 (40\%) (Table I).

A statistically significant difference was determined in NIRS measurements between tissue saturation in areas in which strangulation or incarceration was detected and normal areas. NIRS measurement values ( $\mathrm{rSO}$ ) in hernial areas in which strangulation was detected postoperatively were $65.08 \pm 12.5$ (min-max 39-85). rSO2 values in the normal areas with no hernial sac in the same patient group were $77.92 \pm 10.49$ (min-max 56-95.) The difference was statistically significant

Table I. Patient characteristics and demographic data and a comparison of tissue oxygenation values between incarcerated and strangulated hernial sacs and compared to those in normal areas

\begin{tabular}{|c|c|c|c|c|c|c|c|}
\hline & \multicolumn{3}{|c|}{ Characteristics } & \multicolumn{4}{|c|}{ Number (\%) } \\
\hline & \multicolumn{3}{|c|}{ Age $($ Mean $\pm S D)$} & \multicolumn{4}{|c|}{$65 \pm 14$} \\
\hline & \multicolumn{3}{|c|}{ Male } & \multicolumn{4}{|c|}{$26(65 \%)$} \\
\hline & \multicolumn{3}{|c|}{ Strangulated } & \multicolumn{4}{|c|}{ Incarcerated } \\
\hline & $\mathbf{n}$ & Mean \pm SD & Median (Min-Max) & $\mathbf{n}$ & Mean $\pm S D$ & Median (Min-Max) & $\mathbf{p}^{*}$ \\
\hline NIRS measurements in herniated areas & 24 & $65.08 \pm 12.52$ & $65(39-85)$ & 16 & $67.63 \pm 15.62$ & $73(35-86)$ & 0.572 \\
\hline Measurements in normal areas & 24 & $77.92 \pm 10.49$ & $77(56-95)$ & 16 & $81.81 \pm 9.58$ & $83.5(6 I-93)$ & 0.241 \\
\hline$P^{* *}$ & \multicolumn{3}{|c|}{$<0.001$} & \multicolumn{4}{|c|}{$<0.001$} \\
\hline
\end{tabular}

"Independent Samples t-test; " Paired t-test. NIRS: Near-infrared spectroscopy; SD: Standard deviation; Min: Minimum; Max: Maximum. 


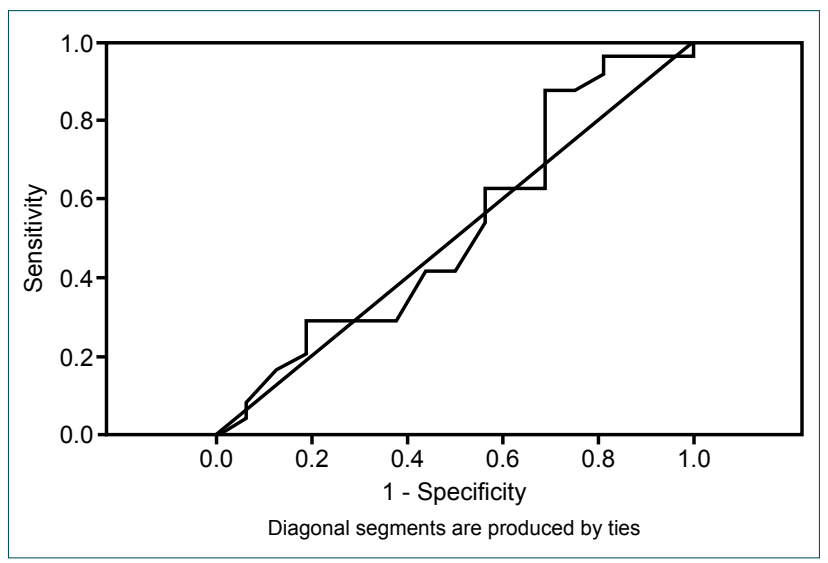

Figure 3. ROC analysis between regions with strangulation and incarceration.

$(p<0.001)$. Tissue saturation in the hernia area of patients with irreducible incarcerated hernial sacs was $67.63 \pm 15.62$ (min-max 35-86), compared to 81.8I \pm 9.58 (min-max 6I-93) in normal areas in the same patient group. The difference between the incarcerated areas and normal areas was statistically significant $(p<0.00 I)$ (Table I). No statistically significant difference was determined between hernial sacs with strangulation and incarceration. In other words, NIRS can detect strangulation or incarceration, but could not detect impaired intestinal oxygenation and strangulation inside the hernial sac $(p=0.572)$. No statistically significant difference was determined when all groups were compared concerning oxygenation of normal areas $(p=0.24 I)$ (Table I).

No significant difference was determined in the ROC analysis performed for measurements between the hernial sacs with strangulation and incarceration. Incarceration and strangulation in the intestines inside the hernial sac could not be differentiated based on the study data $(p<0.815)$. However, it provided clear information concerning intestinal ischemia when compared with the normal areas of the same patients. Oxygenation in the hernial sac decreased when the analysis was performed between normal areas and hernial sacs in the same patient group (Fig. 3). Either strangulation or incarceration in the hernial sac can be detected with NIRS. According

Table 2. ROC analysis of the tissue oxygenation values between incarcerated and strangulated hernial sacs, and compared to those in normal areas

\begin{tabular}{lcc}
\hline & Delta & Saturation \\
\hline Area under the curve & 0.522 & 0.772 \\
Cut-off & $>19$ & $\leq 66$ \\
P & 0.815 & 0.0001 \\
Sensitivity & $31.25 \%$ & $52.50 \%$ \\
Specificity & $87.5 \%$ & $87.5 \%$ \\
\hline ROC: Receiver Operating Characteristics. &
\end{tabular}

to these findings, tissue saturation $\leq 66$ indicates that strangulation or incarceration is present in the hernial sac (sensitivity $=52.50 \%$, specificity $=87.50 \%$ ) (Table 2).

\section{DISCUSSION}

Intestinal tissue oxygenation of irreducible hernias was lower than that in normal areas. On the basis of these findings, irreducible hernias indicated impaired blood flow in intestinal tissues trapped within the hernial sac. Although previous studies have evaluated the oxygenation of the intestines and intra-abdominal organs, to our knowledge, this is the first study to investigate intestinal oxygenation in incarcerated hernias. ${ }^{[24-28]}$

The principal reason for the comparison of intestinal oxygenation inside the irreducible hernial sac with that in intestinal tissue in the normal, contralateral side was to obtain a basal value. It was anticipated that oxygenation in the hernial sac would be lower than that in normal regions since the intestines are trapped and blood flow is impaired, as shown in Figure I. More importantly, even lower oxygenation was anticipated in conditions in which the blood flow is completely stopped, known as strangulation. Decreased intestinal oxygenation was determined in both strangulation and incarceration. NIRS was capable of identifying compromised intestinal oxygenation, but not to the extent of differentiating strangulation from incarceration. Several previous studies support these findings. Arterioles that supply the intestinal wall and venules smaller than $\mathrm{I} \mathrm{cm}$ in diameter are suitable for NIRS measurement. The principal reason for our low measurements is the impairment of this arterial and venous oxygenation in the intestines. A previous study comparing jugular venous oxygen saturation, and hepatic venous oxygen saturation with NIRS measurements to confirm hypoxia occurring globally in the body (in the brain and other organs) described NIRS as a non-invasive and practicable technique. In that study, Li et al. ${ }^{[29]}$ compared cerebral and abdominal tissue oxygen saturation values in newborns undergoing cardiopulmonary surgery with oxygenation markers, such as systemic oxygen delivery, oxygen extraction rate, mean arterial pressure, pulmonary blood flow, systemic blood flow, and superior vena cava saturation. A significant correlation was determined between NIRS measurements and these oxygenation markers and it was concluded that NIRS is a good method for monitoring abdominal oxygenation. Given that this study involved newborns is important concerning the measurements eliciting accurate results. Due to the distance between the INVOS 5100c probes, tissue oxygenation can be measured to a depth of approximately $3-4 \mathrm{~cm}$. It can be considered that $\mathrm{Li}$ et al.'s measurements gave positive results since the abdominal skin in newborns is very thin. The advantage of the patients in the current study is that the intestinal tissue had passed the abdominal wall and approached the subcutaneous region. The high accuracy rate can be attributed to the low depth of intestinal tissues approaching the skin. 
One of the studies providing the most support for the idea that intestinal oxygenation in incarcerated hernias can be assessed using NIRS was that of Toraman et al. They set out to monitor abdominal saturations in patients on whom they performed coronary bypass surgery to determine whether or not abdominal saturation would decrease. The advantage of that study was that skin thickness in the abdominal region was measured using ultrasonography. NIRS probes were attached to points from which appropriate measurements could be made. USG measurements elicited a hepatic skin distance of $2.1 \pm 0.5 \mathrm{~cm}$ and a renal skin distance of $4.2 \pm \mathrm{I} .5$ $\mathrm{cm}$. Oxygenation was monitored with an INVOS 5100 device. It was stated that this was a practical method for monitoring the oxygenation of intra-abdominal organs, particularly in thinner patients. ${ }^{[30]}$ Since no complication, such as hypoxia developed in any of the patients, no statistically significant difference could be determined between pre-, peri-, and postoperative values. However, it was reported that had hypoxia developed in patients, it could have been identified with NIRS. In the current study, no difference was determined between incarcerated and strangulated hernia measurements. This can be attributed to the entrapment of irreducible intestinal tissue and impaired blood flow. Since intestinal tissue blood flow in normal areas was not impaired, it is not surprising that oxygenation should be better than in incarcerated hernias.

Another study supporting these findings was performed by Varela et al. ${ }^{[28]}$ Ischemia can be determined using NIRS in conditions in which abdominal pressure increases, known as abdominal compartment syndrome. Varela et al. stated that NIRS could reveal early changes in mesenteric and systemic perfusion. Abdominal circulation was evaluated in that study using mesenteric artery catheterization, an invasive technique, while simultaneously assessing tissue saturation using NIRS. No significant difference was determined in abdominal saturation measurements between invasive techniques and NIRS, and it was therefore proposed that NIRS can be employed for the purpose described. The authors also suggested that changes in mesenteric perfusion can affect systemic perfusion and that changes in systemic perfusion in the early stages can be detected using NIRS, thus supporting the hypothesis of the current study. Tissue saturation in the Valera et al.'s study was measured from the anterior abdominal wall. Since the current study measurements were performed directly from the hernial sac, this appears to be a good method of assessing intestinal blood circulation, or intestinal perfusion.

Another advantage of the current study is that intestinal oxygenation in non-herniated normal areas exhibited no statistical difference in any of the patients. Despite individual variations, these findings show that NIRS assessed the oxygenation of intestinal tissue with good blood flow very well. Low measurement values in all patients in incarcerated or strangulated hernias, and the absence of any difference between patients, is also a finding of good oxygenation evaluation.

\section{Limitations}

The main limitation of this study was the low number of patients. Further, multi-center studies with larger patient populations may provide further confirmation of this theory. The second limitation of this study was that no NIRS measurements were performed from the hernial region after surgery in patients where intestinal resection was not performed. Intestinal saturation within the sac could have been re-assessed with new measurements performed post-surgically. Another limitation of the study was that the abdominal wall blood supply was not analyzed, although hypoxia developing in the hernial area in the abdominal wall might have affected the measurements. The assessment of vessels supplying the abdominal wall using Doppler ultrasound might have imparted greater value to this study. In particular, evaluation using Doppler ultrasound of the arteria iliaca externa and arteria thoracica interna that supply the abdominal wall might have made a particular contribution to this research. Further studies assessing variations between abdominal wall thicknesses may elicit more definitive information concerning measurement depth.

\section{Conclusion}

In conclusion, in the light of the findings of this study, although not capable of differentiating incarceration from strangulation, NIRS appears to be a good method for showing impaired intestinal oxygenation. NIRS can be used to support ultrasonography findings in irreducible hernias. Therefore, this technique could be used in the future to evaluate and monitor intestinal oxygenation in the ED D.

Ethics Committee Approval: Approved by the local ethics committee.

Peer-review: Internally peer-reviewed.

Authorship Contributions: Concept: A.K., M.Z., O.B., G.E.; Design: A.K., M.Z., O.B., G.E.; Supervision: O.U., S.K., A.K.; Fundings: A.K., G.E.; Materials: M.Z., A.K., O.B., G.E.; Data: M.Z., A.K., O.B., G.E.; Analysis: D.E.; Literature search: A.K., O.B., M.Z., G.E.; Writing: A.K., M.Z.; Critical revision: S.K., A.K., O.U., O.B., G.E.

Conflict of Interest: None declared.

Financial Disclosure: The autors declared that this study has received no financial support.

\section{REFERENCES}

1. Derici H, Unalp HR, Nazli O, Kamer E, Coskun M, Tansug T, et al. Prosthetic repair of incarcerated inguinal hernias: is it a reliable method? Langenbecks Arch Surg 2010;395:575-9. [CrossRef]

2. Kalkan A, Bilir O, Ersunan G, Ozel D, Tas M, Memetoglu ME. Abdominal oxygen saturation for monitoring return of spontaneous circulation in out-of-hospital cardiac arrest using near infrared spectrophometry. Am J 
Emerg Med 2015;33:344-8. [CrossRef]

3. DeWitt AG, Charpie JR, Donohue JE, Yu S, Owens GE. Splanchnic near-infrared spectroscopy and risk of necrotizing enterocolitis after neonatal heart surgery. Pediatr Cardiol 2014;35:1286-94. [CrossRef]

4. Meng L, Gelb AW, Alexander BS, Cerussi AE, Tromberg BJ, Yu Z, et al. Impact of phenylephrine administration on cerebral tissue oxygen saturation and blood volume is modulated by carbon dioxide in anaesthetized patients. Br J Anaesth 2012;108:815-22. [CrossRef]

5. Asim K, Ozlem B, Gokhan E, Zihni Y, Deniz O, Mahmut T, et al. The Use of Cerebral Oximetry in Acute Carbon Monoxide Intoxication: A Preliminary Study. Keio J Med 2015;64:57-61. [CrossRef]

6. Asim K, Gokhan E, Ozlem B, Ozcan Y, Deniz O, Kamil K, et al. Near infrared spectrophotometry (cerebral oximetry) in predicting the return of spontaneous circulation in out-of-hospital cardiac arrest. Am J Emerg Med 2014;32:14-7. [CrossRef]

7. Gay AN, Lazar DA, Stoll B, Naik-Mathuria B, Mushin OP, Rodriguez MA, et al. Near-infrared spectroscopy measurement of abdominal tissue oxygenation is a useful indicator of intestinal blood flow and necrotizing enterocolitis in premature piglets. J Pediatr Surg 2011;46:1034-40.

8. Cortez J, Gupta M, Amaram A, Pizzino J, Sawhey M, Sood BG. Noninvasive evaluation of splanchnic tissue oxygenation using near-infrared spectroscopy in preterm neonates. J Matern Fetal Neonatal Med 2011;24:574-82. [CrossRef]

9. Dani C, Pratesi S, Barp J, Bertini G, Gozzini E, Mele L, et al. Near-infrared spectroscopy measurements of splanchnic tissue oxygenation during continuous versus intermittent feeding method in preterm infants. J Pediatr Gastroenterol Nutr 2013;56:652-6. [CrossRef]

10. Bozzetti V, Paterlini G, Meroni V, DeLorenzo P, Gazzolo D, Van Bel F, et al. Evaluation of splanchnic oximetry, Doppler flow velocimetry in the superior mesenteric artery and feeding tolerance in very low birth weight IUGR and non-IUGR infants receiving bolus versus continuous enteral nutrition. BMC Pediatr 2012;12:106. [CrossRef]

11. Ersunan G, Bilir O, Kalkan A, Kalkan Y, Ozel D, Kayayurt K, et al. Utility of near infrared spectrophotometry in mesenteric ischemia: an experimental study. J Near Infrared Spectroscopy August 4, 2018. [CrossRef]

12. Kim B, Robinson P, Modi H, Gupta H, Horgan K, Achuthan R. Evaluation of the usage and influence of groin ultrasound in primary and secondary healthcare settings. Hernia 2015;19:367-71. [CrossRef]

13. Kraft BM, Kolb H, Kuckuk B, Haaga S, Leibl BJ, Kraft K, et al. Diagnosis and classification of inguinal hernias. Surg Endosc 2003;17:2021-4.

14. van den Berg JC, de Valois JC, Go PM, Rosenbusch G. Detection of groin hernia with physical examination, ultrasound, and MRI compared with laparoscopic findings. Invest Radiol 1999;34:739-43. [CrossRef]

15. Torricelli A, Contini D, Dalla Mora A, Pifferi A, Re R, et al. Neurophotonics: non-invasive optical techniques for monitoring brain functions. Funct Neurol 2014;29:223-30. [CrossRef]

16. Ferrari M, Quaresima V. A brief review on the history of human functional near-infrared spectroscopy (fNIRS) development and fields of application. Neuroimage 2012;63:921-35. [CrossRef]

17. Arridge SR. Optical tomography in medical imaging. Inverse Problems
1999;15:R41-93. [CrossRef]

18. Leff DR, Orihuela-Espina F, Elwell CE, Athanasiou T, Delpy DT, Darzi AW, et al. Assessment of the cerebral cortex during motor task behaviours in adults: a systematic review of functional near infrared spectroscopy (fNIRS) studies. Neuroimage 2011;54:2922-36. [CrossRef]

19. Meng L, Cannesson M, Alexander BS, Yu Z, Kain ZN, Cerussi AE, et al. Effect of phenylephrine and ephedrine bolus treatment on cerebral oxygenation in anaesthetized patients. Br J Anaesth 2011;107:209-17.

20. da Costa CS, Greisen G, Austin T. Is near-infrared spectroscopy clinically useful in the preterm infant?. Arch Dis Child Fetal Neonatal Ed 2015;100:F558-61. [CrossRef]

21. Naulaers G, Meyns B, Miserez M, Leunens V, Van Huffel S, Casaer P, et al. Use of tissue oxygenation index and fractional tissue oxygen extraction as non-invasive parameters for cerebral oxygenation. A validation study in piglets. Neonatology 2007;92:120-6. [CrossRef]

22. Edmonds HL Jr, Ganzel BL, Austin EH 3rd. Cerebral oximetry for cardiac and vascular surgery. Semin Cardiothorac Vasc Anesth 2004;8:14766. [CrossRef]

23. Fellahi JL, Butin G, Fischer MO, Zamparini G, Gérard JL, Hanouz JL. Dynamic evaluation of near-infrared peripheral oximetry in healthy volunteers: a comparison between INVOS and EQUANOX. J Crit Care 2013;28:881.e1-881.e8816. [CrossRef]

24. Westgarth-Taylor C, de Lijster L, van Bogerijen G, Millar AJ, Karpelowsky J. A prospective assessment of renal oxygenation in children undergoing laparoscopy using near-infrared spectroscopy. Surg Endosc 2013;27:3696-704. [CrossRef]

25. Gillam-Krakauer M, Cochran CM, Slaughter JC, Polavarapu S, McElroy SJ, Hernanz-Schulman $\mathrm{M}$, et al. Correlation of abdominal $\mathrm{rSO} 2$ with superior mesenteric artery velocities in preterm infants. J Perinatol 2013;33:609-12. [CrossRef]

26. Nahum E, Skippen PW, Gagnon RE, Macnab AJ, Skarsgard ED. Correlation of near-infrared spectroscopy with perfusion parameters at the hepatic and systemic levels in an endotoxemic shock model. Med Sci Monit 2006;12:BR313-7.

27. Said MM, Niforatos N, Rais-Bahrami K. Validation of near infrared spectroscopy to measure abdominal somatic tissue oxygen saturation in neonates. J Neonatal Perinatal Med 2013;6:23-30. [CrossRef]

28. Varela JE, Cohn SM, Giannotti GD, Dolich MO, Ramon H, Wiseberg JA, et al. Near-infrared spectroscopy reflects changes in mesenteric and systemic perfusion during abdominal compartment syndrome. Surgery 2001;129:363-70. [CrossRef]

29. Li J, Van Arsdell GS, Zhang G, Cai S, Humpl T, Caldarone CA, et al. Assessment of the relationship between cerebral and splanchnic oxygen saturations measured by near-infrared spectroscopy and direct measurements of systemic haemodynamic variables and oxygen transport after the Norwood procedure. Heart 2006;92:1678-85. [CrossRef]

30. Toraman F, Ustalar Özgen S, Arıtürk C, Sayın J, Erkek E, Güçlü P, et al. Is It Efficient to Use NIRS to Calculate Hepatic and Renal Oxygen Saturation During Extracorporeal Circulation?. ACU Sağlık Bil Derg 2012;3:164-9. 
ORİIINAL ÇALIŞMA - ÖZET

Strangüle ve inkarsere hernilerin değerlendirilmesinde yeni bir teknik: Near infrared spectroscopy

Dr. Murat Ziyan, ${ }^{1}$ Dr. Asım Kalkan, ${ }^{2}$ Dr. Özlem Bilir, ${ }^{1}$ Dr. Gökhan Ersunan, ${ }^{1}$

Dr. Deniz Özel, ${ }^{3}$ Dr. Özlem Uzun, ${ }^{4}$ Dr. Semih Korkut ${ }^{5}$

${ }^{1}$ Recep Tayyip Erdoğan Üniversitesi Tıp Fakültesi, Acil Tıp Anabilim Dalı, Rize

${ }^{2}$ Okmeydanı Egitim ve Araştırma Hastanesi, Acil Tip Kliniği, İstanbul

${ }^{3}$ Akdeniz Üniversitesi Tıp Fakültesi, Bioistatistik Anabilim Dalı, Antalya

${ }^{4}$ Bağcılar Egitim ve Araştırma Hastanesi, Acil Tip Kliniği, İstanbul

${ }^{5}$ Kartal Dr. Lütfi Kırdar Egitim ve Araştırma Hastanesi, Acil Tip Kliniği, İstanbul

AMAÇ: Bu çalışmamızın amacı, redükte edilemeyen inguinal hernilerde bağırsak oksijenizasyonunu değerlendirmek için yeni bir yöntem olan near infrared spektrofotometri (NIR) spektroskopi tekniğini kullanmaktır. Böylece erken dönemde bağırsak oksijenizasyonu hakkında bilgi edinmeyi ve NIRS'nin kullanılabilirliğini değerlendirmeyi amaçladık.

GEREÇ VE YÖNTEM: Çalışmamıza inguinal hernileri olup elle redükte edilemeyen ve klinik bulgu ve görüntüleme yöntemleri ile ileus tespit edilen 40 hasta alındı. Hastaların inguninal herni olan bölgeleri ile tam lateralinde herni olmayan bölgelerine NIRS propları yapıştırılarak bağırsak oksijenizasyonları ölçüldü. Normal ve herni olan bölgeler arasındaki oksijenizasyon farkları değerlendirildi.

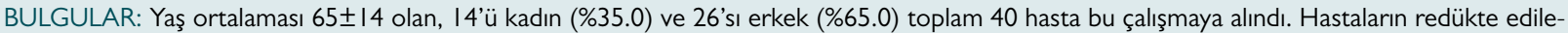
meyen herni bölgesinde bağırsak oksijenizasyonları normal bölgelerine göre düşüktü $(p<0.001)$. Bağırsak oksijenizasyonları düşük olan inguinal herni keseleri ameliyat edildiğinde inkarserasyon ve/veya strangülasyon tespit edildi. NIRS ölçümlerinin düşük ölçülmesi bağırsaktaki inkarserasyon ve/ veya strangülasyonu tespit edebiliyordu fakat ikisi birbirinden ayırt edilemiyordu.

TARTIŞMA: Bu çalışmanın bulguları ışı̆ında, strangülasyondan hapsedilmeyi ayırt edememesine rağmen, NIRS bozulmuş bağırsak oksijenasyonu için iyi bir yöntem olarak görünmektedir. NIRS, indirgenemez fitıklarda ultrasonografi bulgularını desteklemek için kullanılabilir. Bu nedenle, gelecekte acil serviste bağırsak oksijenasyonunu değerlendirmek ve izlemek için bu teknik kullanılabilir.

Anahtar sözcükler: İntestinal oksijenizasyon; oksimetri; redükte edilemeyen herni.

Ulus Travma Acil Cerrahi Derg 2020;26(2): I78-I85 doi: I0.|4744/tjtes.2019.72627 